\title{
СТРУКТУРА САЙТУ «КНИГА ФАНФІКІВ» ЯК МАЙДАНЧИК ПОПУЛЯРИЗАЦІЇ ЖАНРУ ФАНФІКШЕНУ
}

\begin{abstract}
Анотація. Досліджено структуру сайту «Книга Фанфіків» як майданчика для оприлюднення й розповсюдження творів у жанрі фанфікшену, виявлено основні навігаційні елементи сайту, а також окреслено змістове наповнення всіх його рубрик, зокрема «Фанфіки», «Автори», «Популярне», «Заявки», «Бети», а також підрубрик. Вивчено дефініщії понять «фанфікшн» $\mathrm{i}$ «фанфік». Наголошено на жанрових особливостях фанфікшену як різновиду літературного контенту і як нового жанру постмодерної літератури. Виділено причини низької популярності українських спеціалізованих фан-сайтів: мовна ознака й мала кількість українських фікрайтерів (письменників у жанрі фанфікшену). До специфічних ознак сайту належить те, що тут відвідувачам тлумачать значення нових термінів «фанфік», «бета-рідер» та ін., а навігаційна система задовольняе потреби і авторів, і читачів, і потенційних редакторів твору.
\end{abstract}

Ключові слова: сайт, рубрикація сайту, жанр фанфікшену, фанфік, Книга Фанфіків, літературний контент.

Romaniuk Nataliia, Kravchuk Sofiia Zaporizhzhia National University

\section{STRUCTURE OF A WEB SITE «FUNFIC BOOK» AS A PLATFORM FOR POPULARIZATION OF THE GENRE OF FANFICTION}

Summary. The article examines the structure of the site "Fanfic Book" as a platform for the publication and distribution of works in the genre of fanfiction. The definitions of the concepts "fanfic" and "fanfiction" are studied. By fanfic we mean a piece of work written on the basis of a famous book or movie using their main characters, environment or other elements of a story. In the article there are highlighted features of the genre of fanfiction as a type of literary content and as a new genre of postmodern literature: amateur piece of work that derives from a popular fiction book (or movie) or is its alternative continuation, it is published more often on specialized fan sites including the site that is an archive of fanfiction with non-commercial works "Fanfic Book", which is also the largest platform for publication of original works. The reasons for the low popularity of Ukrainian specialized fan sites are outlined: the language feature and the small number of Ukrainian fiction writers (writers in the genre of fan fiction). It is emphasized that the site contains the main rubrics "Fanfics", "Authors", "Popular", "Requests", "Betas", and each of them has its own subsections with a navigation system that helps to find a work or author with certain preferences really quickly (genre, popularity, etc.). Subsections reveal the content of fan fiction, introduce authors and people-betas (editors) who are ready to help authors to improve the text of the work. The specific features of the site include the fact that the meanings of the new terms such as "fan fiction", "beta-reader" and others are explained to the visitors. Such explanations are available for any of the marks - when you place the cursor on an unknown definition, an interpretation of the term is immediately shown. The authors' works, which are written "from scratch" and are not tied to any of the possible characters from the popular pieces of works, are combined in the subsection "Originals". Elements for search and navigation on the web site are sections "Fanfics search" and "Random work", which help readers to choose fan fiction to their taste or to trust a random choice. The navigation system meets the needs of authors, readers and potential editors of the work. The analyzed web site with specific navigation system is a marketing tool, the task of which is to acquaint the guests of the site with its features, and to provide experienced users with a quick transition to the most popular sections of the site.

Keywords: web site, rubrics of a site, fan fiction genre, fanfic, Fanfic Book, literary content.

$\Pi$ остановка проблеми. Глобальна мережа дає безліч можливостей своїм користувачам, зокрема, вона пропонуе розмаїття ресурсів, призначених власне сучасній літературній творчості. Проза та поезія - головні напрямки, на які розраховані письменницькі платформи. Літературні роди й жанри розвиваються, набувають нових ознак, адже людство постійно щось створюе, а це дає поштовх новій формі життя в літературному просторі. Так і виокремився такий специфічний жанр, як франфікшн (від англ. fan - франат, прихильник, i fiction - художня література, вимисел). Незважаючи на те, що це відносно молодий жанр письменництва пострадянського простору, він із кожним роком набуває все більшої популярності й розповсюдженості. I якщо традиційним формам літератури нада- ються окремі платформи в інтернеті, то і франфрікшену, який без відповідного майданчика існувати не може, потрібне таке місце. Так, йому на допомогу приходять спеціалізовані ресурси для публікащії, що забезпечують читацьку базу, оптимізоване налаштування й можливість зворотного зв'язку з аудиторією твору, що надходить до оприлюднення.

На теренах Гугл-пошуковика можна знайти декілька дійсно великих платформ із франфікшену, які є популярними й дієвими, оскільки їхня структура особлива, що якнайкраще сприяе поширенню творів у жанрі франфікшену та їхньому зручному читанню.

Аналіз останніх досліджень і публікацій. Літературні онлайн-майданчики досліджували I. Капраль, Є. Нестерович, А. Гурдуз та ін. Так, 
I. Капраль аналізує особливості фрункціонування найпопулярніших літератур-них електронних видань і сайтів: «ЛітАкцент», «Гоголівська академія», «Сумно?Ком», «Укр.Літ» [5]. Є. Нестерович зосередила свою увагу на інтернеті, який у сучасному літературному процесі $\epsilon$ унікальним простором для самоор-ганізації та реалізащії мистецьких, зокрема літературних проєктів. Дослідниця стверджуе, що сучасна українська література майже не має місця в традиційно-му медіа-просторі, тому інтернет стає «единим доступним простором для комунікації авторів, видавців, критиків та читачів» [7]. Активними комунікативними майданчиками за останні роки стали сайти ЛітАкцент, Буквоїд, Читомо та ін.

Жанр фанфікшену теж не був об'єктом всебічного вивчення. В українському науковому середовищі про цю літературу лише починають писати. А. Гурдуз, О. Невестюк [3] уперше надають франфікшену статусу автономного мистецького явища в жанровому спектрі літератури і тлумачать його як аматорський твір, який є похідним щодо популярних мистецьких, мультимедіатворів (переважно їхнім альтернативним продовженням) і матеріальним носієм якого частіше є спеціалізовані фран-сайти, зокрема «Книга Фанфріків» (далі - КФ). І. Березіна, І. Давиденко розглядають жанрові ознаки літератури франфікшн у контексті їі генологічних зв'язків із фольклором [1]. К. Ігошев аналізуе літературу франфікшн і виділяе наявні їі класифрікації [4]. Жанрова специфріка френомена «франфікшн» була в центрі уваги М. Кузнецової [6].

Виділення не вирішених раніше частин загальної проблеми. У пост-радянському науковому світі грунтовно не вивчали і власне сайти франфікшену як унікально структуровані літературні платформи, чим і зумовлена актуальність нашого дослідження.

Найбільшою платформою для розміщення авторських творів є «Книга Фанфіків» (ficbook.com) - архів франфікшену, сайт, присвячений некомерційним роботам та їхнім перекладам. Однак, як зазначено в розділі FAQ, офріційні видання та їхній переклад під це визначення не підпадають.

Деякі науковці (А. Денисова, А. Жиляева) у своїх роботах розглядали авторські твори, подані на "Книзі Фанфіків", проте досліджували саме текстові складові, а сайти-майданчики залишилися поза увагою вчених. Оскільки франфрікшн - це новий жанр постмодерної літератури, який вирізняеться 3-поміж інших, то і структура відповідних спеціалізованих ресурсів також не $\epsilon$ ординарною, тому й потребують аналізу як ресурси, які адаптовані саме під франдікшн.

Мета статті - виявлення структурних особливостей сайту «Книга Фанфріків» як фрункціонально важливого майданчика для оприлюднення й розповсюдження творів у жанрі франфрікшн. Завданням є: 1) окреслити особливості фрінфрікшену як різновиду літературного контенту; 2) виявити основні структурні та навігаційні елементи аналізованого сайту.

Виклад основного матеріалу. Під поняттям «франфрік» розуміемо «історію, написану шанувальниками будь-якого твору (наприклад, фрільму, серіалу або книги), в якій використову- ються персонажі, світ та інші елементи цього твору». Дослідниця А. Денисова також стверджуе, що франфрік може становити собою продовження, передісторію, пародію, «альтернативний всесвіт», кросовер «переплетення» декількох творів тощо [2]. Водночас франфіком може бути й абсолютно оригінальний твір, написаний автором і оприлюднений під грифром «фанфрікшн». Відповідно, франфіком у загальному розумінні можна вважати витвір сучасного аматорського письменницького мистецтва.

В українському кіберпосторі жанр франфікшену представлений на таких сайтах: Фанфіки Українською Мовою (ФУМ) та Велика Книга Фанфіків $(\mathrm{BК} \Phi)$, проте вони досі не набули достатньої популярності. На те є декілька причин. По-перше, власне українські твори можуть бути мовно доступними тільки аудиторії, що володіє українською, тоді коли російська мова все ж таки є більш розповсюдженою, що забезпечує ширше охоплення аудиторії, зокрема, територіально. По-друге, українських фрікрайтерів (письменників у жанрі франфікшену) суттево менше, що також вплинуло б на кількість публікацій на власне українському ресурсі. Тож поки що одним із найоптимальніших варіантів для розміщення власних творів $е$ «Книга Фанфріків", хоч він як міжнародний майданчик дає змогу публікуватися лише російською, про що зазначено у правилах сайту.

Перше, що показує Гугл, коли знайомить користувача із КФ, - оптимізована зовнішня структура сайту. На запит «Книга Фанфріків» або «фікбук» пошуковик у першому ж результаті відсилає на головну сторінку сайту 3 описом самого ресурсу і його внутрішнім рядком пошуку та пропонуе відсилання на основні рубрики: «Реєстрація», «Оріджинали», «Популярне», «Автор», а також ще два рандомних. Таке налаштування дає змогу користувачам одразу зрозуміти, які фрункції має сайт, і перейти на потрібні позиції безпосередньо зі сторінки Гуглу. Оптимізація не обійшла боком і пошук безпосередньо за назвами робіт. Наприклад, якщо в пошуковику зробити запит "Фанфік ... (назва)», то першою ж відповіддю найімовірніше буде посилання саме на запитувану роботу. Звісно, на випадок, якщо на сайті є декілька робіт зі схожими назвами, у результаті також прописуеться фендом (напрямок, оригінал, за яким написаний твір), та декілька вирізок з опису.

Переходячи на головну сторінку сайту, користувач має змогу ознайомитися з напрямками роботи ресурсу. Саме вона надає відвідувачам інформацію про те, що на КФ «Миллионы историй о твоих любимых персонажах», а «Фанфик - рассказ о героях известного фрильма, книги, аниме, игры и т.д.». Нижче сайт уже сам пропонує зайти через пошуковий рядок франдом, за яким користувач може хотіти прочитати роботу. Для нових гостей сайту запропоновано проілюстровані найпопулярніші франдоми ресурсу - «Оріджинали», «Відьмак», «Дуже дивні справи», «Гаррі Поттер», «Naruto», «Fairy Tail», «Надприродне», «Шерлок (BBC)», «Bangtan Boys (BTS)», «EXO - K/M». Ця сторінка забезпечуе відвідувачів і головними категоріями й напрямками, а також підрубриками «Гарячі роботи» i «Гарячі заявки» із прикладами та лінкуванням на відповідні сторінки сайту. 
Головна сторінка забезпечуе інформаційний запит не лише читачів, а й авторів. Читачам пропонують колекцію готових книг з ілюстраціями їхніх обкладинок. Перейшовши на сторінку авторів, бачимо можливості, які є на сайті: надрукувати свій фанфік чи оріджинал, скориставшись кнопкою «Добавити свій фанфік!», знайти співавтора чи власного читача.

Усі названі можливості $е$ маркетинговою площиною, завдання якої - ознайомити гостей ресурсу з його специфікою, а досвідчених користувачів - забезпечити швидким переходом до найзатребуваніших розділів сайту.

Рубрики із шапки «Книги Фанфріків» надають вільний доступ до свого змістового наповнення. Кожна з них («Фанфіки», «Автори», «Популярне», «Заявки», «Бети») розкривае зміст франфікшену, знайомить 3 авторами та 3 тими, хто готовий допомогти авторам удосконалити власне текст твору. Нижче запропонованих рубрик розміщені пошуково-навігаційні елементи «Добавити франфік», «Пошук фанфікіків» і «Випадкова робота», що дають змогу реалізуватися і авторам, і читачам.

Так, рубрика «Фанфіки» містить підрубрики «Категорії» та «Мітки», які переважно визначають фондомну, жанрову й тематичну спрямованість робіт на сайті. Наприклад, кожна із виділених підрубрик має лінк на різновиди фандомів: у лінку "Аніме і манга" можна знайти фанфіки, написані за творами в цьому сегменті, а підрубрика «Оріджинали» - едина, яка містить праці авторів, написані «з нуля» і які не мають прив'язки до жодного з можливих фондомів.

Мітки становлять собою жанрову приналежність фанфікшену та його можливу сюжетну лінію. Підрубрика «Мітки» розбита на власні категорії, зокрема: «Жанри», «Попередження», «Формат», «Книги (18+)» та багато інших. Названі нами категорії е, на нашу думку, домінантними при виборі твору для прочитання, оскільки можуть як надати читачу результат за його вподобання-ми, так і вберегти від табуйованих ним тем.

Рубрика “Автори" знайомить користувачів із двома ТОП 100 авторів - «Набирають популярність» $\mathrm{i}$ «За весь період». Перший включае список авторів, які отримали більше підписників за останні 7 днів, другий - авторів 3 найбільшою кількістю підписників за увесь час. Обидва рейтинги враховують усіх авторів сайту, а сам підрахунок робиться раз на добу. Такі списки важливіші для самих фікрайтерів, аніж для читачів, проте все-таки несе свою інтерактивну функцію і створюе конкурентне середовище всередині самого майданчика.

Таке ж середовище підтримуеться в рубриці «Популярне». Раз на добу рахуеться кількість оцінок «подобається», поставлених твору за останні 7 днів. До списку ТОП потрапляють роботи, які набрали найбільшу кількість оцінок. Незважаючи на те, що рубрика мае 8 підрубрик («Все», «Джен», «Гет», «Слеш», «Фемслеш», «Статті», «Змішаний» та «Інший»), при розрахунках беруть участь усі твори, незалежно від розміру чи фандому. Так підвищуеться конкуренція серед письменників, а також їхне прагнення до вдосконалення текстів.

Окремим джерелом натхнення є рубрика «Заявки». Заявка - ідея для твору, яку читач пропонуе авторам «Книги Фанфіків» до написання. Так задовольняються потреби обох сторін фанфікшену - автори знаходять цікаві сюжети для майбутніх робіт, а читач отримуе реалізацію власних фантазій. До пропозиції заявок може долучитися будь-хто, адже тут можна ознайомитися з чужими ідеями, які зацікавлять користувача як потенщійного читача. Наприклад, продивившись один із розділів із заявками - «Активні», «Виконані», «Гарячі» і «Архів», читач може підібрати щось на свій смак і одразу ж прочитати запропоновані авторами роботи на задану тему.

Однак якими б майстерними не були автори, вони все ж потребують незалежної думки, поради чи справжньої редакторської правки фанфіків. Саме цю потребу на КФ задовольняе така людина, як бета-рідер. Бета-рідер (скорочено бета) - це своєрідний редактор, який за попередньою домовленістю або з власної ініщіативи допоможе автору в приведенні тексту до бездоганного вигляду та підготуе до оприлюднення. Для бет тут виділена окрема рубрика «Бети", де вони можуть залишати свою анкету як виконавця, описавши франдоми, які полюбляють, свої вподобання, результат тесту на грамотність і досвід роботи із творами на КФ (зазвичай прикріпляеться лінк на опрацьований фанфік). Тут автори й обирають фахівця з потрібними саме їм якостями в меню пошуку, в якому потрібно зазначити напрям, мітки й рівень грамотності, з якими працюе бета. Така фрункція має свою стратегічну значимість - чим кращі за показниками будуть опубліковані роботи, тим більше читачів до них буде заохочено. I це позитивно впливае і на сам майданчик, і на кожного окремого користувача.

Пошуково-навігаційні елементи ресурсу, зокрема «Пошук фонфіків» і «Випадкова робота» надають читачам можливість обрати франфік за власним смаком або довіритися випадковому вибору. I якщо «Випадкова робота» переносить користувача одразу на сторінку запропонованої алгоритмом роботи, то «Пошук франфіків» надає ширший перелік можливостей. Саме цей розділ розкривае особливості фанфікшену серед інших жанрів літератури. Він дозволяе обрати будь-які франдомні, форматні, жанрові, змістові та навіть рейтингові елементи робіт, які користувачу хотілося б взяти до прочитання. Такий спосіб формує чіткий запит читача, в якому буде зазначене все - від бажаних персонажів і критичних сюжетних поворотів до статусу написання роботи й кількості сторінок у ній.

Загалом адміністрація сайту належним чином підготувала майданчик до використання і зовсім недосвідченими, і добре обізнаними гостями сайту. Для цього головні рубрики сайту на своїх сторінках мають розгорнуте пояснення про новітні терміни й поняття. Так, у рубриці «Бети» користувачам одразу ж надаеться тлумачення слова «бета-рідер» та опис головних можливостей, які пропонуе цей розділ. Схожі трактування е і для будь-якої з міток - при наведенні курсору на невідомий термін гостю одразу ж видається визначення поняття. Наприклад, наведений курсор на мітку «ООС» покаже віконечко з роз'ясненням: «Описувані у творі персонажі поводяться зовсім не так, як можна було б очікувати, виходячи з їхнього представлення в каноні». 
Висновки i перспективи подальшого розвитку в цьому напрямку. "Книга Фанфіків» працюе не лише як майданчик для популяризації франфрікшену, його структура перетворює сайт на повноцінне видавництво. На ресурсі представлене розмаїття можливостей як для авторів, так і власне читачів запропонованого літературного жанру. Читач може знайти ро- боту за будь-якою цікавою йому темою, а автор має можливість продемонструвати свою творчість широкій аудиторії в найкращому вигляді. Фанфікшн розвивається, а допомагають йому в цьому саме такі ресурси з їхньою розгалуженою рубрикацією та практично 3 необмеженими можливостями і для авторів, і для читачів, i для редакторів.

\section{Список літератури:}

1. Березіна I.О., Давиденко I.О. Фанфікшн як жанр постфольклору. Наука III тисячоліття: пошуки, проблеми, перспективи розвитку : матеріали IV Міжнародної науково-практичної інтернет-конференції. Бердянськ, 2020. C. 157-158. URL: https://bdpu.org.ua/wp-content/uploads/2020/04/Berezina-I.O.-Davydenko-I.O.pdf

2. Денисова А. Фанфикшен, как субкультура и феномен массовой литературы. Аналитика Культурологии. 2012. № 3(24). URL: http://analiculturolog.ru/journal/archive/item/893-26-2.html

3. Гурдуз А.І., Невестюк О.С. Фанфікшн: парадокси статусу в художньому просторі. Науковий вiсник Міжнародного гуманітарного університету. Серія : Філологія. 2018. № 34. Т. 1. С. 89-91. URL: http://www.vestnik-philology.mgu.od.ua/archive/v34/part_1/24.pdf

4. Ігошев К.М. Проблеми жанрової класифікації літератури франфікшн. Літературний процес: летодологія, імена, тендениії. Збірник наукових праиь (фбілологічні науки). 2019. № 14. С. 22-26.

5. Капраль I.I. Електронні медіа як складова літературного процесу (на прикладі найпопулярніших сучасних українських літературних сайтів). Наукові записки Української акаделії друкарства. Серія : Соціальні комунікацї̈. 2015. № 1. C. 30-36. URL: http://nbuv.gov.ua/UJRN/Nzck_2015_1_6

6. Кузнецова М.О. Жанрова специфіка комунікативно-текстового феносмена «фанфікшен» (на матеріалі саги Дж. Р. Р. Мартіна "A SongofIceandFire»). Нова фбілологія. Запоріжжя, 2014. № 60. С. 93-97. URL: http://nbuv.gov.ua/UJRN/Novfil_2014_60_20

7. Нестерович Є. Електронний фронтир як середовище творення сучасного українського літературного процесу. Вісник Львівського університету. Серія фбілологічна. 2014. Вип. 60(1). С. 348-354. URL: http://nbuv.gov.ua/ UJRN/Vlnu_fil_2014_60\%281\%29_45

\section{References:}

1. Berezina I.O. (2020) Fanficshion yak zhanr postfolkloru [Fan fiction as a genre of post folklore]. Nauka III tysiacholittya: poshuky, problem, perspectyvy rozvytku: materialy IV Mizhnarodnoi naykovoi-praktychnoi internet-konferentsii. Berdyansk, pp. 157-158. URL: https://bdpu.org.ua/wp-content/uploads/2020/04/BerezinaI.O.-Davydenko-I.O.pdf

2. Denysova A. (2012) Fanfikshn, kak subkultura i fenomen massovoi literatury [Fan fiction as a subculture and phenomenon of mass culture]. Analitika Kulturologii, no. 3(24). URL: http://analiculturolog.ru/journal/archive/ item/893-26-2.html

3. Gurduz A.I., Nevestyuk O.S. (2018) Fanfiction: paradoks statusu v hydozhnyomu prostori [Fan fiction: paradox of status in literary space]. Naykovuj visnyk Mizhnarodnogo gumanitarnogo universytetu. Seriya: Filologiya, vol. 1 , pp. 89-91. URL: http://www.vestnik-philology.mgu.od.ua/archive/v34/part_1/24.pdf

4. Igoshev K.M. (2019) Problemy zhanrovoi klasyfikatsii literatuty fanfikshn [Problems of genre classification of fan fiction literature]. Literaturnyj protses: metodologiya, imena, tendentsii. Zbirnyk naukovyh prats (filologichni nauky), no. 14, pp. 22-26.

Kapral I.I. (2015) Elektonni media yak skladova literaturnogo protsesu (na prykladi najpopulyarnishyh ukrainskyh literaturnyh sajtiv) [Electronic media as a part of literary process (on an example of the most popular modern Ukrainian literary web sites)]. Naukovi zapysky Ukrainskoi akademii drukarstva. Seriya: Sotsialni komunikatsii, no. 1, pp. 30-36. URL: http://nbuv.gov.ua/UJRN/Nzck_2015_1_6

5. Kuznetsova M.O. (2014) Zhanrova spetsyfika komunikatyvno-tekstovogo fenomena "fanfikshn" (na material sagy Dzh. R. R. Martina "A SongofIceandFire") [Genre specifics of communicative-textual phenomenon «fan fiction» (on the material of saga by G. R. R. Martin «A SongofIceandFire»). Nova filologiya. Zaporizhzhia, no. 60, pp. 93-97. URL: http://nbuv.gov.ua/UJRN/Novfil_2014_60_20

6. Nesterovych E. (2014) Elektronnyj frontyr yak seredovyshche tvorennya suchasnogo ukrainskogo literaturnogo protsesu [Electronic frontier as an environment for the creation of modern Ukrainian literary process]. Visnyk Lvivskogo universytetu. Seriya filologichna, issue 60(1), pp. 348-354. URL: http://nbuv.gov.ua/UJRN/Vlnu_ fil_2014_60\%281\%29_45 